eCommons@AKU

May 1988

\title{
Epidemic non-A non-B hepatitis in urban Karachi, Pakistan
}

RAJr Smego

A A. Khaliq

Aga Khan University

Follow this and additional works at: https://ecommons.aku.edu/ pakistan_fhs_mc_med_gastroenterol

Part of the Gastroenterology Commons

\section{Recommended Citation}

Smego, R. A., Khaliq, A. A. (1988). Epidemic non-A non-B hepatitis in urban Karachi, Pakistan. The American Journal of Tropical Medicine and Hygiene, 38(3), 628-632.

Available at: https://ecommons.aku.edu/pakistan_fhs_mc_med_gastroenterol/185 


\title{
EOSINOPHILIC GASTROENTERITIS
}

\author{
Pages with reference to book, From 316 To 317 \\ Syed Hasnain Ali Shah ( Departments of Medicine, The Aga Khan University Hospital, Karachi. ) \\ Zaigham Abbas, Shahab Abid, Tahir Qaseem, Haleem Khan ( Department of Medicine, The Aga Khan University Hospital, \\ Karachi. ) \\ Hizbullah Shaikh ( Departments of Pathology, The Aga Khan University Hospital, Karachi. )
}

There has been a case report from Pakistan ${ }^{1}$, in which a fifteen year old male presenting with anaemia, pyloric outlet obstruction and a mass in the upper abdomen is described. The case presented here is a bit unusual in its late age of onset and lack of involvement of the gastric antrum. An almost immediate response to steroid therapy is, however, quite classical of this condition.

\section{CASE REPORT}

M.A.S., a 74 year old male was admitted in the hospital with a six weeks history of watery diarrhoea, six to eight stools per day, which was treated at home with lomotil and immodium to partial benefit only. He complained of crampy abdominal pains and mild nausea. There was no history of bleeding or passage of mucus per rectum. He vomited twice on the day of admission, There was no history of fever, weight loss or general ill health during this illness. In 1983, he had undergone coronary artery bypass graft operation and suffered a cerebrovascular accident in 1987. He was non-smoker and teetotaller. On examination, he was distressed, pulse was 70/minute, regular, blood pressure was 110/70 $\mathrm{mmHg}$ and there were no signs of heart failure. Hs temperature was $37.4^{\circ} \mathrm{C}$. Abdominal examination revealed tenderness all over. There was no visceromegaly and no evidence of ascites. Bowel sounds and rectal examination findings were normal. On examination of the chest and musculoskeletal system no abnormality was noted. Neurological examination revealed signs of old left hemiparesis. Investigations showed a haemoglobin of $15.5 \mathrm{~g} / \mathrm{di}$, TLC 21,200/ui, DLC=neutrophils 42\%, eosinophils 41\%, lymphocytes $16 \%$ and monocytes $1 \%$, ESR $2 \mathrm{mmHg} / \mathrm{hr}$. Bilirubin $0.5 \mathrm{mg} / \mathrm{dl}$, SGPT $10 \mathrm{IU} / \mathrm{L}$, alkaline phosphatase $63 \mathrm{IU} / \mathrm{L}$, total proteins $4.5 \mathrm{~g} / \mathrm{dl}$, albumin $2.1 \mathrm{~g} / \mathrm{dl}$, BUN $18 \mathrm{mg} / \mathrm{dl}$, creatinine $1.3 \mathrm{mg} / \mathrm{dl}$. Abdominal ultrasound was normal. Stool D/R examination revealed more than $10 \mathrm{WBC}$ 's/HPF, no fat al occult blood. Charcot leydon crystals and eosinophils were absent. No enteric pathogens were isolated on culture. His serum IgE was found to be greater than $200 \mathrm{IU} / \mathrm{ML}$ (normal 10-180 IU/ML). The differential diagnosis at this stage included a bacterial infection of the gut, helminthic infection, polyarteritis nodosa, lymphoma of gut and eosinophilic gastroenteropathy. He was treated with fiagyl and ofloxacin for 10 days to no benefit. Ftexible signoidoscopy and upper gastrointestinal endoscopy was done which revealed normal looking mucosa and no significant abnormality in motility pattern. Multiple biopsies were taken from rectum, sigmoid and descending colon, eosophagus, gastric antrum, duodenum and jejunum. Gastric biopsies did not show any significant abnormality but small intestinal biopsies (Figure 1) 


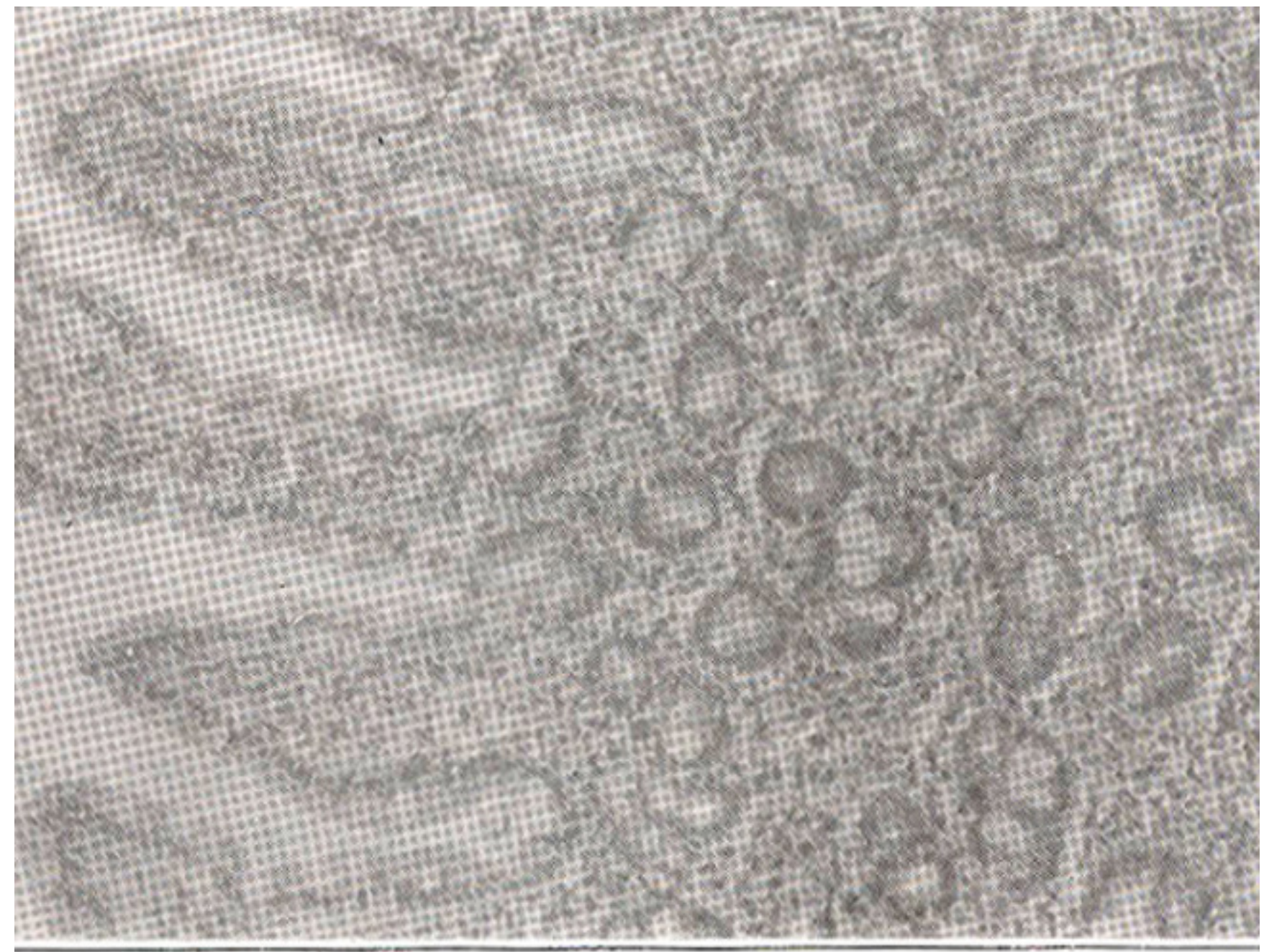

Figure 1. Small bowel biopsy showing normal villous pattem and infiltration of inflammatory cells with eosinophil polymorphs (x 200) H\&E stain.

revealed moderately heavy infiltration of cells predominantly eosinophils, in the lamina propria. The villous pattern was normal. Biopsies from colon and rectum (Figure 2) 


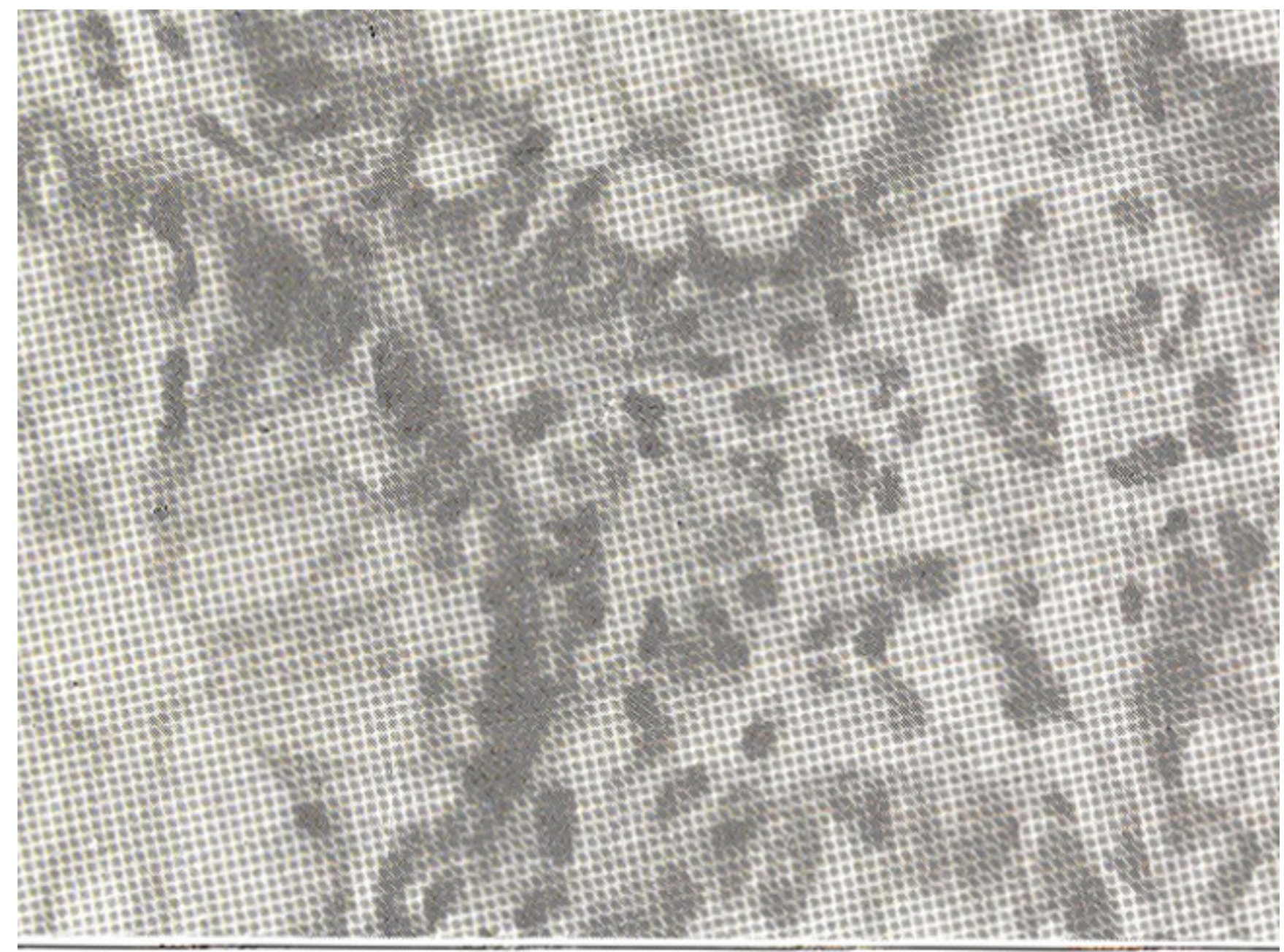

Figure 2. Large bowel tissue showing inflammation in the lamina propria with eosinophils $(x$ 400) H\&E stain.

showed moderately heavy infiltration of chronic inflammatory cells including large number of eosinophils. Tubular glands did not show any significant distortion or mucin depletion. Initiation of prednisolone $40 \mathrm{mg}$ a day stopped the diarrhoea within 48 hours and his eosinophil count came down to $1 \%$. However, he developed high grade fever and blood cultures grew pseudomonas. This was treated with ceftazidime and prednisolone was stopped. The fever subsided and the patient continued to be in remission of diarrhoea till discharge a week later.

\section{DISCUSSION}

Eosinophilic gastroenteritis (EG) demonstrates a rare but well recognized disease of the gastrointestinal tract. The peak age of presentation is in the third decade, though no age is exempt. Males are affected more than females $(3: 2)^{1}$. The etiology is unknown, but food allergy specially to milk is a possible causative factor and radio-allergosorbent test (RAST) for IgG milk antibodies is often positive. Results of good challenges to substances to which the patient is thought to be allergic are usually positive ${ }^{2}$. An unusual case of EG is presented here. Eosinophilic infiltration of the gastrointestinal tract is variable in its depth of bowel wall involvement and extent of bowel length involved. However, 50-70\% o patients have involvement of gastric antrum which may be patchy and, therefore, multiple biopsies are advised from this region ${ }^{3,4}$. Mucosal and submucosal infiltration of the gastrointestinal tract give rise to 
symptoms of nausea/vomiting and/or diarrhoea with malabsorption depending on the segment of gastrointestinal tract involved. Bleeding from gastrointestinal tract may also be a feature of the disease. Muscle layer infiltration with eosinophils produces rigidity and marked thickening of the bowel, which may give rise to symptoms of obstruction. Serosal involvement presents with peritonitis and ascites. Extra intestinal involvement includes infiltration of the urinary bladder, prostate and gallbladder. Accompanying allergic phenomena such as eczema, rhinitis and asthma pccur in upto 50\% of patients. Treatment includes a trial of elimination diet which helps in a minority of patients ${ }^{5}$. Medications, which have been tried, include ketotifen, an eosinophilic degranulation preventing substance and sodium cromoglycate. Both of these, however, have not produced any good results. The only medication which seems to work is steroid therapy. The initiation of therapy in a dose of up to $40 \mathrm{mg}$ a day controls

diarrhoea within a week. The treatment can be gradually tapered off but sometimes patients need 5 to $10 \mathrm{mg}$ a day of maintenance treatment to remain in remission.

\section{REFERENCES}

1. Blackshaw, A.J. and Levison, D.A. Eosinophilic infiltrates of the gastrointestinal tract.J. Gilt,. Pathol., 1986; 39:1.

2. Caldwell. 3.11., Tennehaum, J.L. and Bronstein, HA. Serum IgE in eosinophilik gastroenteritis: Response to intestinal challenge in two cases. N. EngI. 3. Med., 1975 292:1388.

3. Katz, A.J., Goldman, H. and Grand, R.J. Gastric mueosal biopsy in eosiinophilic (allergic) gastroenteritis. Gastroenterology, 1977; 73:705.

4. Cello, J.P. Eosinophilie gastroenteritis - A complex disease entity. Am. 3. Med.. 1979; 67:1097.

5. Greenberger, NJ., Tennebaunt, J.I. and Ruppert, RD. Protein- losing enteropathy associated with gastrointestinal allergy. Am. J.Med., 1967; 43:777.

6. Kazi, 3.1., Alam, SM., Khan, A.A. and Ara, J. Eosinophilie gastritis. JPMA.. 1987; 37:9. 